\title{
MEANINGS IN THE PROCESS OF SIGNIFICATION OF LANCÔME'S BEAUTY SERUM ADVERTISEMENTS
}

\author{
Cliff Albert Tuna, Esther Harijanti Kuntjara \\ English Department, Faculty of Letters, Petra Christian University \\ Surabaya, East Java, Indonesia \\ e-mail: clifftuna054@gmail.com, estherk@petra.ac.id
}

\begin{abstract}
Through this study, the writer aimed to find out how meanings are created in advertisements video. The three objectives of this study are to find out how meanings are created through verbal expressions, how the visual expressions of the advertisements support the verbal expressions and to find out the differences between the two advertisements. The data used to conduct this study were Lancôme Génifique Serum Advertisement (2009) and Lancôme Advanced Génifique Serum (2013). After analyzing the data with the research questions in mind, the writer found out that meanings in both advertisements are created through the verbal captions and what were visually shown on the advertisement videos. The writer also found out that there were a few differences between the first and second advertisements. The second advertisement provides more appealing visuals, more direct and convincing verbal expressions and more facts and needed information regarding the promoted product. These factors make the second advertisement an improved version of the first one.
\end{abstract}

Key words: Process of Signification, Denotation, Connotation

\section{INTRODUCTION}

In the business world, advertisement is considered one of the most important elements of the business as a whole. It bridges the gap between the company and its potential market. In other words, advertisement is the tool that reaches out to the market with the purpose to introduce and persuade people to buy the products that are being sold. Over the years, advertisement has grown into a huge industry. In fact, we can almost conclude that good advertisement marketing is more important than the quality of the advertised products itself.

In today's world, people are bombarded by advertisement on a daily basis. We are surrounded by advertisements wherever we go, and even though those hundreds and hundreds of advertisement comes in different forms, they all have one in common; their goal is to persuade people to buy the products that they are promoting. The most prominent thing in advertisement is imagery and texts, so by using the process of signification, the writer will be able to analyze and explain the visual and verbal elements of the advertisements that are being analyzed on this thesis.

The data of analysis that the writer has chosen are two television advertisements of Lancôme beauty serums. These are two different products that are called Génifique Concentrate (2009) and Advanced Génifique Concentrate (2013). Firstly launched in 2009, the serum instantly became one of the brand's top best-selling products. The serum was the first product that opened the gate for other products in the line of Génifique after the initial launching. In 2013, Lancôme brought a newly formulated version of Génifique that was called Advanced Génifique. By launching the new version of the serum, Lancôme discontinued the older one along with the other products on the particular line. Following the business strategy of the previous serum launch, Lancôme firstly launched the serum and then introduced more products, like night cream and eye cream, into the Advanced Génifique line as time went by.

Although the first edition of Génifique line was a huge success, Lancôme wanted to step up their achievement in not only creating and launching a new version of Génifique serum but also a better advertisement to represent it. In this research, the writer wanted to analyze how the second advertisement differs from the first one and how the changes they made improved the overall advertisement quality and effectiveness.

In this research, the writer chose to analyze the advertisements of Lancôme beauty serum through the videos to understand how meaning is created in the process of signification. Through this 
research, the writer hopes that readers can understand how meaning is created using the visual and verbal elements on the advertisements. Also, the writer would like to unravel the connections between the verbal language and the visual language used in the data that the writer analyzed and the impact in projecting a certain impression and in persuading people to buy the promoted product. The overwhelming amount of sales figure that great advertisements helped to generate is definitely saying something. It is a tangible proof that advertisement is an important factor in a launch of a product.

In doing the research, the writer had three objectives to achieve. First, how meaning is in the advertisement created through the verbal expression. Second, how meaning is in the advertisement supported by the visual expression. Lastly, the writer wanted to find out the differences between the first and second advertisement.

\section{METHODS}

In effort to describe the meaning of the two advertisements of Lancôme, the writer conducted the research using Descriptive Qualitative Method. "Meaningful" descriptive qualitative method reveals not only the on-the-surface meaning of a social reality, but also the deep meaning of it. In other words, this method focuses on the reasons of certain behaviors in a social situation (Mukhtar, 2013). By using this method, the writer will be able to identify the verbal and visual expressions used on the advertisements and analyze the meaning behind them.

Data analysis was the process after the writer had done the data collection completely. The data for the analysis consists of verbal and visual expressions. For the verbal expressions which are in the form of captions or sentences, the writer put all of them in a table. After that, the writer analyzed the denotation and connotation meaning of each caption briefly. Later on, in the fourth chapter, the writer analyzed each caption in-depth, mainly focusing on the connotation meaning. For the visual expressions, the writer gathered all of them in a table to reveal the denotation and connotation meanings and categorized each one of them as an icon, index or symbol.

Later on the chapter four where the verbal and visual expressions are analyzed in a more indepth manner, the writer started analyzing the verbal expressions by choosing a certain keyword in each caption and looked for the definition in the Oxford Advanced Learner's Dictionary. After getting the definition, the writer analyzed the verbal expressions (captions) as a whole complete sentence. In the process of analyzing, the writer tried to reveal both the denotation as well as the connotation meanings of each caption.

Then, the writer analyzed the visual expressions in the advertisements; relate them with the verbal expressions to answer the second research question. In the process of analyzing the visual expressions, the writer analyzed how visual expressions support the verbal expressions. In the analysis, the writer also explained each visual expression as an icon or index.

Lastly, the writer analyzed the difference between the first advertisement and the second one. At this stage, the writer did not only explain the obvious differences between the two advertisements like the duration and number of expressions but also focused on the differences in terms of the content of the advertisements. Finally, the conclusion of all the analysis will be presented at last.

\section{ANALYSIS AND FINDINGS}

In this part the writer analyzes the verbal expressions in Lancôme's Génifique Serum video advertisement. The 15 -seconds long video was released in 2009 and contains five verbal expressions. The writer analyzes the verbal expressions individually to explain the meaning behind each caption. First, the finds the definitive meaning on certain keywords of the captions using the Oxford Advanced Learner's Dictionary and then analyzes each caption as a whole complete sentence with Descriptive Qualitative Method. Lastly, after analyzing all the verbal expressions on this advertisement, the writer retells the whole analysis as a connected short story as a summary.

Below are shown a few representatives to show how Lancôme Génifique Serum Advertisement (2009) creates meanings through the verbal expressions that are shown inside the advertisement video. 
Youth is in your genes, reactive it: According to the Oxford Advanced Learner's Dictionary, the word "youth" means the quality or state of being young. In this first verbal expression, youth is portrayed as something natural that everyone has within oneself. However, it also implies that people have inactive youth within them. As we all know, as people get older, they lose the quality of youthfulness in every part of their body, including the facial skin. By reactivating the youthfulness, people can once again have the youthfulness they have lost.

It is clear that the target market of this serum is people who notice their skin has started aging, people who have started losing their youthfulness in their complexion and want to regain and maintain the youthfulness in their skin. "Youth is in your genes, reactivate it", isn't this sentence full of hope? It is exactly what these people want to hear. Contrary to popular belief that getting older and having old skin is inevitable and can't be restored back to its youthful condition, the sentence states that even though you have lost your youthfulness, you can definitely get it back!

Reactivating youthfulness is not an act of making something miraculous happens out of the blue. Reactivating youthfulness is an action of bringing back something that you have inside you, your sleeping youthfulness that had started sleeping after you got older, and bringing it back to life again. It is possible not only because the serum is powerful, but because the youthfulness itself is something that you already have within you.

So after convincing people that it is indeed possible to restore youthfulness, people start wondering what they can do to reactivate their youthfulness. What product should I use?

Génifique: Youth Activator: The word Génifique is the name of the substance that the serum contains. According to dictionary, the word "activate" refers to the action of making something such as a device or chemical process to start working. So, in this case, activator is the cause of a skin chemical process to start. The advertisement suggests the idea that everyone has a "sleeping youthfulness" inside oneself. Now, because the youthfulness is asleep, it needs to be awakened or brought to life. This substance called Génifique is the ultimate ingredient that everyone needs to bring their youthfulness back to life. The advertisement suggests that no matter what products you use on your skin, you would never be able to awaken your youthfulness because in order to do, you need to reactivate the youth within you and of course only Lancôme has the youth activator in their serum.

There are many anti-aging products on the market that promise to brighten, moisturize, or firm the skin along with many others claims that they have. However, Lancôme is the only brand that brings up the concept of a "youth activator", a substance that reactivates someone's skin youthfulness that had stopped working due to aging. The caption implies that in order to get your youthful skin back, you only this one thing that will change everything and transform your skin. One interesting thing about the concept of youth activator is that everyone has the potential to regain youthfulness. The advertisement says that youth is in your genes; however you must reactivates the youth within you. How? By putting the activator on your skin and it will do its magic.

To summarize, in this advertisement, Lancôme introduces a new product with some impressive claims. The video suggests that youthfulness is a quality that everyone has within oneself. However, as we all know, as people get older, they start losing their youthfulness. With this video, Lancôme suggests that the youthfulness that everyone has can actually be rejuvenated once again. With their magical substance called Génifique that literally means Youth Activator, anyone can bring out their youthfulness on the surface and look young in just seven days. This video also shows how substance that is called Génifique works. It works by boosting the activity of the skin to reveal young glowing skin. Overall, the video implies that there is only one product that can reactivate skin's youthfulness and that product is called Lancôme Génifique Serum. The reason is simply because only Lancôme that has this Génifique substance that can reactivate the youthfulness inside anyone.

Below are shown a few representatives to show how Lancôme Advanced Génifique Serum Advertisement (2013) creates meanings through the verbal expressions that are shown inside the advertisement video.

The secret of youthful skin is in your hands: This is the opening narration of the advertisement. This caption sounds very promising and inviting. Youthful skin is something that everyone wants; the firm texture, the glow; the smoothness that it has. However, as people get older, they start to lose the youthfulness that they once had. Getting older is so inevitable it makes most people forget that restoring skin youthfulness, to certain extend, is actually achievable. 
According to dictionary, the word "secret" means something that is "kept hidden from others". The caption suggests that now you can possess the secret that can transform skin with any kind of conditions. Isn't it amazing to get a hold of something so secretive that is hidden from most people? Furthermore, if it is secret, then it is surely powerful! There is only very little percentage of people that actually manage to look young while getting old, some of them take good care of their skin, while some of them are just lucky to have such good genetics. But for sure, people in general experience aging while they are getting older and older.

So to have youthful skin, you need to take good care of your skin from early age on a daily basis or you can have good genetics. However, you cannot choose to have good genetics. So, for those people without the good skin genetics but want to regain their youthful skin, they can get their hands on this secret of youthful skin, which is a serum by Lancôme with the name Advanced Génifique Serum. So buy the serum, and youthful skin is yours forever.

Inspired by gene science: According to the dictionary, the word "gene" is a cell unit that controls a particular quality in a living, and "science" is knowledge about the structure and behavior of the natural and physical world. So "gene science" refers to the special knowledge about the gene, and in this case, skin genetics. The sentence shows that the serum is a product that is supported by a special knowledge about the human complexion. With the special knowledge of the skin genetics, the serum is packed with ingredients that are accurately effective in bringing out the youthfulness on anyone's skin.

Anyone who hears the word science would relate the word to advanced technology and years and years of research. In science, people constantly try to improve their knowledge and understanding about things, that's why science has always brought the most advanced technology in the world. "Inspired by gene science" suggests the idea that this serum possesses the most advanced technology in skincare. Gene science indeed makes it possible to bring back youthfulness that has left the skin. It obviously sounds too good to be true to hear that looking young again is possible, but with science it definitely is a reality!

So, in this second advertisement video we can see that Lancôme has become more explicit in their effort in delivering the message of their product. By simply using the word "science", Lancôme has successfully given the impression of the nature of the product. It implies that power that makes this product able to transform anyone's skin is science. Science is indeed a powerful word that has a strong connotation. In this second advertisement video, we will be seeing more examples in which Lancôme explicitly present their product.

Now, this is the explanation and answer for the second research question which is how the visual expressions support the verbal expressions on both advertisements. There will be only a few examples for the visual expression explanation for both advertisements since the full version of the analysis will take too much space.

This first advertisement video starts with a blinding light opening up the screen. An "index" is defined by sensory features that implies to a certain meaning or conclusion. So in this case, the dramatic opening scene of the video is an index (see Figure 1). It implies that something miraculous is being revealed. Indeed, the video is introducing a new groundbreaking anti-aging serum that contains a magical substance that can reactivate the youthfulness in anyone's skin. That magical substance is called Génifique that literally means Youth Activator. Later in the video, it is explained how the magical substance work on the skin to transform it.

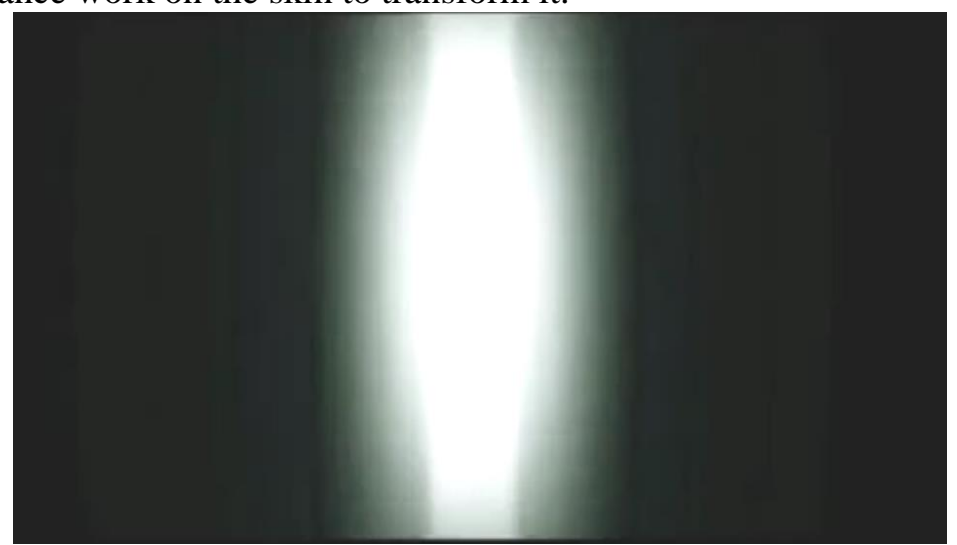


Figure 1

Throughout the video, the background stays consistent with showing moving black bars. Right from the beginning of the video, the moving black bars are shown on the background to frame the serum in the center of the screen. On a deeper level, we can see that the black bars is an index for human genetics. Human genetics, when shown on a picture, looks like a structure of lines that are organized in two spiraling lines that face each other (see Figure 2). The moving black bars on the background are shown to make a connection to the human genetics (Figure 3).

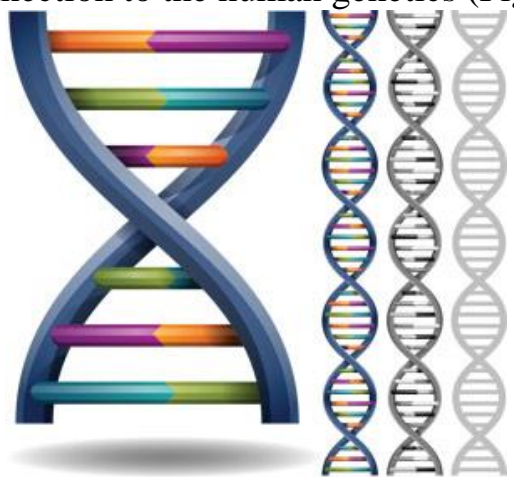

Figure 2

On the second advertisement, the video starts by showing the bottom part of the serum bottle with the dropper inside (see Figure 3). The purpose of this opening scene is to showcase the features of the serum which are the liquid serum and the dropper so that people can see them. This visual expression can be considered as an icon because it represents the actual product that is being advertised. This visual expression showcases how the goodness of the product to allure the audience to buy the product. The serum is looking sparkling and shimmering which makes it look like a mesmerizing magical substance.

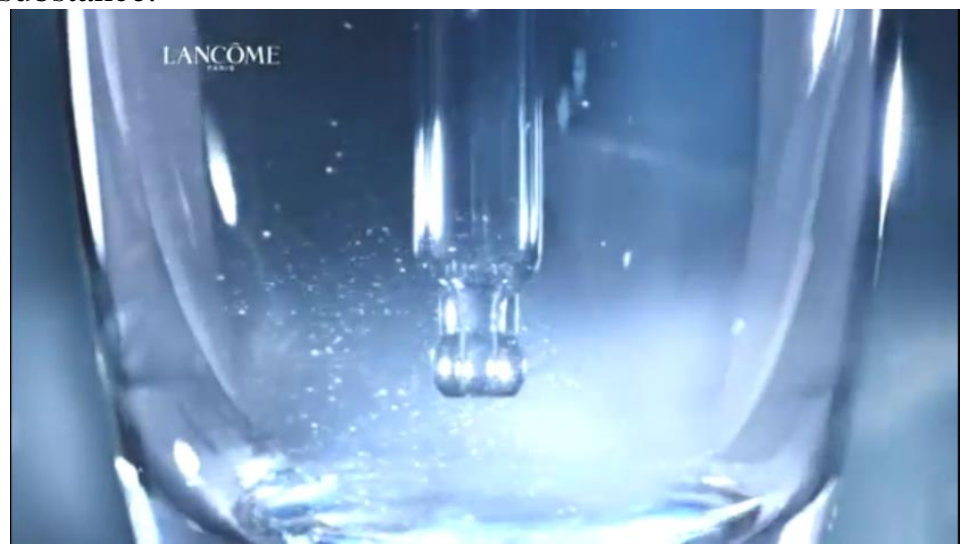

Figure 3

Shortly after, the model hand appears to be holding the serum bottle. This visual expression is an icon for showing how the bottle looks like in real life. This visual expression represents the actual thing that it stands for; it shows the physical feature of the actual product. This visual expression is also in synched with the first verbal expression (The secret of youthful skin is in your hands) and it reinforces the message even more. The way the model holds the bottle is specifically planned; it looks like as if she were holding something that is so treasured and important.

The video shows sparkling Da Vinci's-inspired square and circle figure surrounding the serum bottle (see Figure 4 below). The visual technology applied on this scene is so sophisticated that it creates this amazing sparkling effect surrounding the serum bottle. This visual expression is in synced with the verbal expression that says "Inspired by gene science". There are two purposes of showing this scene; the first one is to show how sophisticated the design of the bottle is and to imply the idea that this product is a result of advanced technology that is inspired by gene science. This visual expression is both an icon and an index because it shows the actual product but at the same time implies the idea of advanced science. 


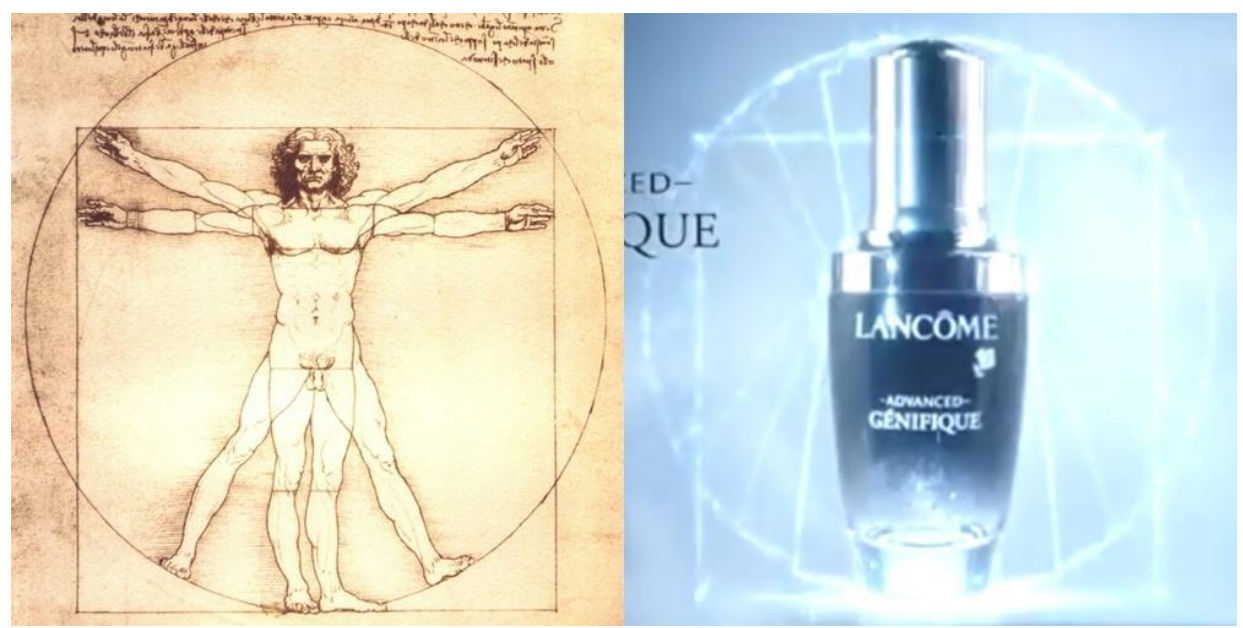

Figure 4

To answer research question number 3, there are a few main points that the second advertisement had done differently than the first one which will be explained further shortly. The first thing that second advertisement does differently is to showcase more visually appealing visual effects. This is apparent and can be seen throughout the whole advertisement. The visual effects also strengthen the theme of the product of the second advertisement (Lancôme Advanced Génifique Serum) which focuses on "Scientific" and "Magical" power that the serum contains. "Scientific" visual expressions can be seen in the visual expression that shows the serum bottle with the Da Vinci's inspired figure on the background. In this case, the Da Vinci's human anatomy figure represents the scientific background that the serum has.

The second difference is that the second advertisement contains verbal expressions that are much more direct and convincing. We can see this by reading the verbal expressions of the second advertisement. Verbal expressions like "The secret of youthful skin is in your hands" and "Inspired by gene science" clearly deliver a message that is more direct. These two verbal expressions are more direct that they deliver the message as if they were talking to the audience. These two verbal expressions are like saying, "This is the secret that will change your skin and it is a product of an advanced technology that is so powerful in bringing back the youthfulness of the skin". Verbal expressions like "Our \#1 Serum, "Skin feels younger on your fingertips", and "Feel youthful skin, see glowing skin" show that the verbal expressions on the second advertisement are more direct and highly suggestive. So the writer concluded that the second advertisement has more direct verbal expressions.

The third difference of the two advertisements is that the second advertisement provides more facts and needed information of the product compared to the first one. In their second advertisement (2013) Lancôme shows the benefits of the serum on the screen, all ten of them. Compared the first advertisement (2009), Lancôme did not show benefits of the serum, they only stated "See visibly younger skin in just seven days" without letting the audience know what will happen to their skin if they use the serum or how the serum can transform their skin. Another example of showing more facts and information can be seen when the second advertisement (2013) also states that " $78 \%$ of 67 women agree" that the serum delivers the claim on their skin. This verbal expression is shown for ten seconds which is a big portion of the video duration which is only 19 seconds. By showing not only the claims but also the consumer study, people can see that the data is reliable and accurate. This is an improvement because this change helps to explain the product in a better way therefore making it more convincing for people to buy.

Overall, the writer has concluded that there is indeed a big difference between the first and second advertisement video. First of all, the second advertisement provides more visually appealing visuals that go hand-in-hand with the theme of the advertisement. Second, the second advertisement also has verbal expressions that are much more direct and explicit. Lastly, the second advertisement provides more facts and needed information about the promoted product. 


\section{CONCLUSION}

The writer understand that advertisement video deals with signs as it includes both verbal expression and visual expression in the sense that the visual expression supports the verbal expression to make the meaning in the advertisement easier to understand by the viewers. In analysing how meaning is created by the advertisement, the writer used the process of signification to uncover the meaning of signs.

Next, the writer made three research questions to help him to reach the answers of this research. Three research questions are to find out how meaning is created in the advertisement through verbal expression, to find out how meaning in the advertisement is supported by the visual expression, and to find out the difference between the first advertisement video and the second one. First, the writer had to uncover the denotation and connotation meaning of the verbal and visual expressions. Also, in analyzing the visual expressions, the writer had to use a theory that categorizes visual signs into three things which are Icon, Index and Symbol. After that, the writer analyzed each expression in depth with explanation.

In his finding, the writer found out that both verbal and visual expression in the advertisement of Lancôme Génifique Serum (2009) and Lancôme Advanced Génifique Serum (2013) are indeed crucial in conveying a specific meaning that each advertisement wants to convey to the viewers. The writer has found that each verbal expression of the videos convey specific meanings like "Restoring youthfulness is possible" or "Lancôme Advanced Génifique Serum is the only thing that you need to get back your youthful skin". And by aligning the verbal with the visual expressions, the meaning of the video can be very powerful.

In conclusion, meanings in the advertisements videos are created by the connotative meaning of each verbal expression that support and related to each other. Furthermore, the visual expressions support the meaning of the verbal ones by aligning themselves or being in-synced while conveying the same message therefore making the message stronger.

\section{REFERENCES}

Chandler, D. (2007). Semiotics The Basics (2nd ed). London: Routledge.

Da Vinci Human Anatomy (n.d.) (2013). Retrieved November 222016 from http://humanbodyanatomy.us/da-vinci-human-anatomy/

Human Genetics Structure (n.d.) (2010). Retrieved November 112016 from http://scitechdaily.com/study-shows-four-stranded-quadruple-helix-dna-structure-in-humancells/

$\begin{array}{lllllll}\text { Port, R. Linguistics (2000). Retrieved November } 15 & 2016 \text { from }\end{array}$ http://www.cs.indiana.edu/ port/teach/103/sign.symbol.html

Saussure,F. (1974). Course in General Linguistics. London: Fontana

Storey, J. (2009). Cultural Theory and Popular Culture : An Introduction (5th ed).

What is Metabolism? (n.d.) (2009) Retrieved November 222016 from http://www.newsmedical.net/life-sciences/What-is-Metabolism.aspx 